\title{
Big Data in Corporate Governance decision
}

\author{
Inmaculada Bel, Alfredo Grau
}

Department of Corporate Finance, University of Valencia, Spain.

\begin{abstract}
Progress in Big Data in recent years has grown exponentially, which has allowed the detection and processing of a large amount of data. Until recently, this fact was unattainable by the lack of mechanization of the corporate governance reports. This paper investigates the relationship between corporate governance decisions affect the indebtedness policies of 1,956 industrial companies listed in Europe and the USA over the period 2016-2018 (5,868 observations). To measure corporate governance decisions, we use detailed information on the expertise of audit committees, the proportion of independent directors, board structures and women's presence on corporate boards. Our findings, which are based on a static panel data analysis, show that there is a strong negative relationship between Audit Committees expertise and indebtedness level in European and North American companies. There are also evidence that European and American companies with a onetier board structure and Audit Committees expertise are less likely to have lower level of indebtedness. Our results shed new light on corporate governance in relation to the experience of audit committees and the influence of their characteristics on indebtedness policy.
\end{abstract}

Keywords: Big Data; Corporate Governance; Expertise Audit Committees; Business Analytics. 


\section{Introduction}

One of the consequences of the Internet and global interconnection through the network is the enormous volume of information that organizations and the general public have access to. In recent decades, the challenges and opportunities of Big Data management is a relevant issue in business management in general, and in particular, in financial management. Therefore, it can be analysed the impact of obtaining, managing and analyzing data in the different areas of the company: strategic definition and its implementation, corporate decision making, design of financial policies, etc.

Big Data provides a new vision, a future perspective in order to predict what can happen to take advantage of opportunities and thus, anticipate the events with the use of the techniques provided by the "Business Analytics" area. In this way, you can define analytical models that allow you to model the functioning of organizations. Consequently, it highlights the need for a new paradigm of storage, processing and enhancement of Big Data. Organizations which are move in this philosophy and are generators of information become "Data Driven Business", directed towards decision making as well as strategic management.

In line with above arguments, the objective of this work is to analyze the extent to which corporate governance decisions affect the indebtedness policies of industrial companies listed in Europe and the USA. Particularly, special attention is paid to the effect produced by the previous experience of the Audit Committee in the field of finance on the levels of indebtedness of these companies.

The main findings of this manuscript provide evidence that companies which have a one-tier board structure, have lower levels of indebtedness and if they also have Audit Committees with experience in finance, this reducing effect is softened. These results are generalizable for both Europe and the USA, although this effect is more moderate for North American companies.

\section{Theoretical Framework and Hypothesis}

Big Data explains extremely large data sets with large storage capacity that generally need to be analyzed using computational methods (Cockcroft and Russell, 2018). In this sense, companies and research centers are deploying a very rigorous computing power to make sense of the huge amounts of data. A large part of the interest that "big" data is that they have a greater potential to contain more interesting patterns and anomalies than "small" data (Cockcroft and Russell, 2018).

Rehman, Chang, Batool and Wah (2016), among others, characterize Big Data for its volume, velocity and value. Subsequently, IBM and Microsoft added one more feature, veracity, to describe the reliability of the data. However, and according to Bhimani and Willcocks (2014), 
this volume of data which is generated in a continuous and increasing way is largely unstructured. Many of them are likely to be organized in an economically useful sense and quickly processed for decision-making. effective in real time (Krishnan, 2013).

\subsection{Impact of Big Data in Finance}

The use of Big Data in the financial field has developed in recent years very quickly (Ye and $\mathrm{Li}, 2017)$. Despite these advances, there is still little research on how Big Data has influenced the way financial decisions are made, about their impact on strategic responsibilities (Quinn, Dibb, Simkin, Canhoto and Analogbei, 2016), or how this data is handled at the board level (Nutt and Wilson, 2010). However, Big Data offers the potential to reduce risk and improve these strategic decisions by allowing high-level leadership teams to have a more comprehensive vision (Filatotchev and Nakajima, 2010).

Turner, Schroeck and Shockley (2013) consider that Big Data is a source of information and one of the most important assets that organizations have. The financial management business is packed full of transactions that add growing information to the industry. Hence, Big Data offers in finance management the possibility of adopting a more strategic and proactive role within the company (Chua, 2013). In particular, Bhimani and Willcocks (2014) warn against reorienting financial functions to simply harness the potential of big data.

\subsection{Hypothesis}

In the corporate governance field, Audit Committee (AC) characteristics (such as expertise or independence) are considered relevant factors in order to reduce the opportunistic behaviour of managers and by mitigating agency problems (Madi, Ishak and Manaf, 2014). In this sense, investors demand the presence of audit committees in the companies whose members have relevant expertise (Ghafran and O'Sullivan, 2013). Audit committees with financial expertise are considered an internal monitoring mechanism that can mitigate agency problems and tend to impact on indebtedness policy (Javaid and Javid, 2017). Past research has analysed the effect of some aspects of corporate field with the level of debt such as the independent directors (Doan and Nguyen, 2018), audit committees expertise (Carcello, Hollingsworth, Klein and Neal, 2006), firm size (Harford, Li and Zhao, 2007), Board Structure Type (Calza, Profumo and Tutore, 2017), CEO duality (Harris, 2014), board structure type (Pucheta-Martínez, Gallego-Álvarez and Bel-Oms, 2019), gender diversity (Harris, 2014), among others. The hypotheses to study in Big Data context are:

Hypothesis 1: The greater the financial experience of the AC, the lower the indebtedness.

Hypothesis 2: The greater the financial experience of the AC, the greater the negative relationship between the independence board and the indebtedness. 
Hypothesis 3: The greater the financial experience of the AC, the lower the negative relationship between the board structure type and the indebtedness.

Hypothesis 4: The greater the financial experience of the AC, the lower the negative relationship between the women's presence on boards and the indebtedness.

\section{Sample and Variables}

The sample used in this study comprised international firm years observations from THOMSON REUTERS EIKON database from 2016 to 2018. This sample included the industrial sector of all the countries belonging to Europe and USA and is grouped in a static data panel with 1,956 industrial companies and 5,868 observations. We have used the industrial sector is due to the fact that this sector plays a very significant role in the global economy.

The series of the variables used (Table 1) have been filtered to eliminate both the observations with errors or absent, as well as those extreme observations in the distributions. This double filtering process has lead to losing approximately $32.8 \%$ for the USA and $64.4 \%$ for Europe.

Table 1. Description of the explanatory variables.

Parameters Description

\section{Leverage Variable}

LEV Leverage: Total Debts / Equity

\section{Main Explanatory Variables}

\begin{tabular}{ll}
\hline EXA & $\begin{array}{l}\text { Expertise Audit Committees: Dummy variable that takes the value if the members of } \\
\text { the audit committee have financial experience and } 0 \text { otherwise. }\end{array}$ \\
INDBO & $\begin{array}{l}\text { Independence Board: Ratio between the proportion of independent directors on boards } \\
\text { directors and the total members of the board. }\end{array}$ \\
BOTYPE & $\begin{array}{l}\text { Board Structure Type: Dummy variable that takes the value } 1 \text { if the company has a } \\
\text { one-tier board structure and } 0, \text { if the company has a two-tier board structure. }\end{array}$ \\
BGEN & $\begin{array}{l}\text { Board Gender Diversity: Dummy variable that takes the value } 1 \text { if the companies } \\
\text { include female directors on corporate boards and } 0 \text { otherwise. }\end{array}$ \\
\hline CEODU & $\begin{array}{l}\text { CEO duality: Dummy variable that takes the value } 1 \text { if the CEO of the firm also serves } \\
\text { as chairman of the board and } 0, \text { otherwise. }\end{array}$ \\
LSIZE & Company Size: Logarithm of total assets of firms. \\
ROA & Profitability: Profit Before Interest and Taxes / Total Assets.
\end{tabular}




\section{Methodology}

In this section, we analyze the determinants of level of indebtedness and will pay special interest to the effect produced by the financial experience of the Audit Committee. We group the large data into a static panel that will allow us, to some extent, to control the unobservable heterogeneity that could occur in the treatment of these data. The econometric approach is:

$$
\begin{aligned}
\mathrm{LEV}_{\mathrm{jt}}= & \delta_{0}+\delta_{1} \mathrm{EXA}_{\mathrm{jt}}+\delta_{2} \mathrm{INDBO}_{\mathrm{jt}}+\delta_{3} \mathrm{BOTYPE}_{\mathrm{jt}}+\delta_{4} \mathrm{BGEN}_{\mathrm{jt}} \\
& +\left(\delta_{5} \mathrm{INDBO}_{\mathrm{jt}}+\delta_{6} \mathrm{BOTYPE}_{\mathrm{jt}}+\delta_{7} \mathrm{BGEN}_{\mathrm{jt}}\right) * \mathrm{EXA}_{\mathrm{jt}} \\
& +\delta_{8} \mathrm{CEODU}_{\mathrm{jt}}+\delta_{9} \mathrm{LSIZE}_{\mathrm{jt}}+\delta_{10} \mathrm{ROA}_{\mathrm{jt}}+\varepsilon_{\mathrm{jt}}
\end{aligned}
$$

where $L E V_{j t}$ is the level of indebtedness for industrial sector $\mathrm{j}$ in the time period $\mathrm{t}$ calculated as the quotient between the total liabilities and equity. $\delta_{0}$ represents the regression constant. $\delta_{j}$ represents the estimated values of all variables. $\varepsilon_{j t}$ are the random perturbations.

The parameters have been estimated by incorporating instrumental variables through the Generalized Method of Moments (GMM) to the equation in first differences. To measure the goodness of fit are proposed: adjusted $\mathrm{R}^{2}$, contrast of Wald set, and estimation error. In addition, the second order serial correlation $m 2$ test of Arellano and Bond (1991). Furthermore, the over-identification of restrictions Sargan (1958) test. To detect possible multicollinearity problems, we apply the Variance Inflation Factor (VIF). The results obtained for all companies, we confirm the absence of multicollinearity problems since the values of the VIF range between 1.1021 and 7.7763 (Neter, Wasserman and Kutner, 1989).

\section{Results}

Table 2 shows the findings for checking all the hypotheses proposed. Moreover, we want to examine the individual effect of independent variables with the indebtedness policy and the moderating effect of audit committee expertise on the other variables. 
Table 2. Determinants of indebtedness for industrial firms.

\begin{tabular}{|c|c|c|c|c|}
\hline \multirow[b]{2}{*}{ Main Variables } & \multicolumn{2}{|c|}{ EUROPE } & \multicolumn{2}{|c|}{ USA } \\
\hline & Model 1 & Model 2 & Model 1 & Model 2 \\
\hline $\mathrm{C}$ & $-0.173 * *(-1.971)$ & $0.2912(1.465)$ & $0.537(0.729)$ & $0.594(0.814)$ \\
\hline EXA & & $-0.417 * *(-2.047)$ & & $-0.072 *(-0.122)$ \\
\hline INDBO & & $0.035(0.206)$ & & $1.152 *(0.323)$ \\
\hline ВОТYРЕ & & $-0.108 * *(-2.727)$ & & $-0.068 * *(-1.366)$ \\
\hline BGEN & & $-0.058(-0.327)$ & & $-0.978(-0.304)$ \\
\hline \multicolumn{5}{|l|}{ Cross Effects } \\
\hline INDBO*EXA & & $-0.046(-0.246)$ & & $-1.093(-0.288)$ \\
\hline BOTYPE*EXA & & $0.119 * *(2.418)$ & & $0.056 *(1.975)$ \\
\hline BGEN*EXA & & $0.194(0.939)$ & & $1.08(0.331)$ \\
\hline \multicolumn{5}{|l|}{ Control Variables } \\
\hline CEODU & $-0.036(-0.734)$ & $-0.032(-1.162)$ & $0.085 *(0.619)$ & $0.015(0.115)$ \\
\hline LSIZE & $0.042 * * *(9.136)$ & $0.032 * * *(4.966)$ & $0.004 * *(0.115)$ & $0.001 *(0.016)$ \\
\hline ROA & $-0.953 * * *(-15.543)$ & $-0.934 * *(5.748)$ & $-0.189 * *(-1.300)$ & $-0.185^{* *}(-1.296)$ \\
\hline$R^{2}$ adjusted & 0.0424 & 0.0828 & 0.1102 & 0.1641 \\
\hline Wald & $293.99 * *$ & $9541.85 * *$ & $2442.76 * *$ & $12528.60 * *$ \\
\hline Est. error & 1.2241 & 0.9394 & 1.0378 & 0.9666 \\
\hline m2 Test & 0.92 & 0.74 & 0.96 & 0.88 \\
\hline Sargan Test & $62.67(69)$ & $91.66(73)$ & $71.66(69)$ & $76.52(72)$ \\
\hline
\end{tabular}

\footnotetext{
The data correspond to regression results of GMM model in first differences, described in the equation (1). tStatistic in brackets. Chi-squared: degrees of freedom in brackets for Sargan Test. $*^{* *} \mathrm{p}<0.01,{ }^{*} \mathrm{p}<0.05,{ }^{*} \mathrm{p}<0.1$
}

The results obtained for Europe are the following. Model 1 provide evidence that the firm size has a positive (at 1\%). However, the profitability presents a negative (at $1 \%$ ). These results confirm the premise that companies with higher size, results in a higher indebtedness policy and lower levels of return on assets. In Model 2, the coefficient of EXA variable is negative (at 5\%). Hence, we confirm the explanatory power of this variable and hence, the, compliance with Hypothesis 1. Our evidence suggests that European firms with include this committee tend to support a lower level of leverage, in line with Badolato, Donelson and Ege 
(2014). Moreover, we examine the impact of board structure (BOTYPE) and policy of indebtedness. This finding provide evidence that the coefficient is negative (at 5\%).

The BOTYPE*EXA is positive and of opposite sign to the main variable in Europe and the USA. This result leads us to accept the Hypothesis 3. As a consequence, European firms with a one-level board structure are less likely to have a lower level of indebtedness when there is a greater effect of this committee, in line with Pucheta-Martínez et al. (2019).

According to the results for USA, Model 1 provide evidence that the duality of CEO and firm size have a positive (at $10 \%$ and $5 \%$, respectively). However, the profitability presents a negative sign (at 10\%). These results confirm that when the CEO of the firm also serves as chairman of the board and when the companies have higher size, results in a higher debt policy and lower levels of return on assets.

In Model 2, the coefficient of EXA is negative (at 5\%). This finding leads us to accept the Hypothesis 1, which suggests that American firms with include an audit committee with directors with financial experience tend to support a lower level of indebtedness. On the other hand, the results also findings that the proportion of independent directors on corporate boards (INDBO) shows a positive sign (at 10\%), contrary to our predictions. According to this result, companies which include independent directors tend to increase the indebtedness policy. Furthermore, the variable board structure type (BOTYPE) presents a negative sign (at 5\%). Therefore, all companies) with a one-tier board structure and Audit Committees expertise (BOTYPE*EXA) are less likely to have lower level of indebtedness. Furthermore, the variable board structure type exhibits a negative sign (at 10\%). Therefore, the Hypothesis 3 has not to be rejected. Our finding suggests that companies located in USA with a one-tier board structure are less likely to have lower level of indebtedness when there is higher effect of audit committee expertise.

In respect of cross effects analyzed for the proportion of independent directors on corporate boards (INDBO*EXA) and gender diversity (BGEN*EXA), they do not present statistical significance. Consequently, we should reject Hypothesis 2 and Hypothesis 4.

\section{Conclusions}

The aim of this investigation is to study, in the Big Data environment, the extent to which corporate governance decisions affect the indebtedness policies of industrial companies listed in Europe and the USA. We have paid special attention to the effect produced by the previous experience of the Audit Committee in the field of finance on the indebtedness levels.

The European and North American companies with a one-level board structure are less likely to have a lower level of debt when there is a greater effect of the audit committee's experience. While it is true that the financial formation of this committee, in itself, allows reducing the 
volume of debt, when it acts in an organization where the governance structure is unique, this effect is less expansionary. This could be explained by the fact that this financial expertise leads the audit committees to drive an optimal capital structure that does not necessarily imply a simple reduction in indebtedness, but that these levels are the most appropriate for industrial companies listed. Moreover, in board structure unitary when all board members have the same responsibilities and functions, independent directors may be not fulfill their monitory duties. This fact reduces the credibility and objectivity of the board members when monitoring managerial team and ultimately, may reduce in lower level the indebtedness policy. These findings are observed for firms listed in both markets, although it should be noted that this effect has less impact in the USA.

Several implications can be derived from this analysis. Firstly, the findings of this investigation provide evidence that there is a limited presence of female directors on corporate boards. In this sense, our manuscript has a relevant value for government and regulatory bodies, because it allows them to note that there is under-representation of women on boards for Europe and USA, since there is not effect on the leverage with or without crossing effect. Policymakers should recommend the representation of female directors on boards since they behave as a control mechanism that improves the financial decisions of the companies. Second, regulators in Europe and USA should made efforts to consider audit committee members with financial expertise as internal control mechanisms in the companies. This evidence should lead policymakers to consider the benefits to inclusion of financial experts on audit committees to the stakeholder. Third, this evidence may be useful for managers who are willing to enhance the indebtedness policy, as we show that companies reduce the indebtedness if there is Audit Committees expertise and one-tier board structure.

Our study's findings should be considered with caution. The sample used in this study is based on European and North American Companies on the industrial sectors, although the study revealed some factors that are not found in the past research yet. Further research can focus on investigating if the Audit Committee experience has an effect on the making decision process of the indebtedness policy in other countries such as Latin-America or Asia.

\section{References}

Arellano, M., \& Bond, S. (1991). Some tests of specification for panel data: Monte Carlo evidence and application to employment equations. Review Economics S., 58, 277-97.

Badolato, P., Donelson, D., \& Ege, M. (2014). Audit committee financial expertise earnings management: The role of status. Journal of Accounting and Economics, 58, 208-230.

Bhimani, A., \& Willcocks, L. (2014). Digitisation, "Big Data" and the Transformation of Accounting Information. Accounting and Business Research, 44, 469-90.

Calza, F., Profumo, G., \& Tutore, I. (2017). Boards of directors and firms' environmental proactivity. Corporate Governance and Organizational Behavior Review, 1(1), 52-64. 
Carcello, J., Hollingsworth, C., Klein, A., \& Neal, T. (2006). Audit committee financial expertise, competing corporate governance mechanisms, and earnings management. Competing Corporate Governance Mechanisms, and Earnings Management.

Chua, F. (2013). Big Data Essential to Commercial Accountants.

Cockcroft, S., \& Russell, M. (2018). Big Data Opportunities for Accounting and Finance Practice and Research. Australian Accounting Review, 28(3), 323-333.

Doan, T., \& Nguyen, N. Q. (2018). Boards of directors and firm leverage: Evidence from real estate investment trusts. Journal of Corporate Finance, 51, 109-124.

Filatotchev, I., \& Nakajima, C. (2010). Internal and external corporate governance: An interface between organization and its environment. British J. Management, 21, 591-606.

Ghafran, C., \& O'Sullivan, N. (2013). The governance role of audit committees: reviewing a decade of evidence. International Journal of Management Reviews, 15(4), 381-407.

Harris, C. K. (2014). Women directors on public company boards: does a critical mass affect leverage?Business and Economics Faculty Publications. 29. Available at: https://digitalcommons.ursinus.edu/bus_econ_fac/29

Harford, J., Li, K., \& Zhao, X. (2007). Corporate boards and the leverage and debt maturity choices. SSRN Electronic Journal.

Javaid, H., \& Javid, S. (2017). Determining agency theory framework through financial leverage \& insider ownership. International Journal Economics and Finance, 9, 21-28.

Krishnan, K. (2013). Introduction to big data. In K. Krishnan (Ed.), Data warehousing in the age of big data: A volume in MK series on business intelligence. Morgan Kaufmann.

Madi, H., Ishak Z, Manaf, N. (2014) The impact of audit committee characteristics on corporate voluntary disclosure. Procedia-Social and Behavioral Sciences, 164, 486-492.

Neter, J., Wasserman, W., \& Kutner, M.H. (1989). Applied regression models. IL: Irwin.

Nutt, P., \& Wilson, D. (2010). Handbook of decision making. London: Wiley.

Pucheta-Martínez, M. C., Gallego-Álvarez, I., \& Bel-Oms, I. (2019). Board structures, liberal countries, and developed market economies. Do they matter in environmental reporting? An international outlook. Business Strategy and the Environment, 28(5), 710-723.

Quinn, L., Dibb, S., Simkin, L., Canhoto, A., \& Analogbei, M. (2016). Troubled waters: The transformation of marketing in a digital world. European J. Marketing, 50, 2103-33.

Rehman, M., Chang, V., Batool, A., \& Wah, T. (2016). Big data reduction framework for value creation in sustainable enterprises. International Journal of Information Management, 36(6), 917-928.

Sargan, J. (1958). The estimation of economics relationships using instrumental variables. Econometrica, 26, 393-415.

Turner, D., Schroeck, M., \& Shockley, R. (2013). Analytics: The Real-world Use of Big Data in Financial Services, IBM Global Business Services: 27.

Ye, M. \& Li, G. (2017). Big Data, big decisions: Internet big data and capital markets: a literature review. Financial Innovation, 3(6), 3-18. 